\title{
As súplicas a Zeus Suplicante na tragédia As Suplicantes de Ésquilo
}

\author{
JAA TORRANO \\ Universidade de São Paulo \\ Brasil
}

\begin{abstract}
Resumo. Nas tragédias de Ésquilo, a “dialética trágica”, bem como as noções e imagens próprias do pensamento mítico grego, estão a serviço da elaboração do pensamento político, que reflete sobre os limites inerentes a todo exercício de poder, as relações de poder e a questão da Justiça na pólis. Este artigo visa demonstrar essa hipótese da "dialética trágica", mediante o estudo analítico-interpretativo da tragédia As Suplicantes de Ésquilo.

Palavras-Chave. Ésquilo; tragédia; As Suplicantes; pensamento mítico; pensamento político; dialética trágica.
\end{abstract}

Nas tragédias de Ésquilo, as vidas - cujo sentido está em questão e em jogo no desenvolvimento do drama - se decidem no interior de um quádruplo diálogo, em que falam Deuses, Numes, heróis e mortais, e no qual se confundem e se distinguem quatro pontos de vista, correspondentes aos graus de verdade do conhecimento e aos graus de participação no ser, pertinentes aos mortais e às instâncias dessa hierarquia do divino, tradicional entre os gregos desde Homero, a saber: Deuses, Numes e heróis. A essas distinções entre pontos de vista divinos, numinosos, heróicos e humanos e entre graus diversos de participação na verdade e no ser, chamamos "dialética trágica": icástica, pré-filosófica, própria do pensamento mítico grego arcaico e clássico. Essa "dialética trágica”, bem como as noções e as imagens também próprias do pensamento mítico grego, estão, nas tragédias de Ésquilo, a serviço da elaboração do pensamento político, que reflete sobre os limites inerentes a todo exercício de poder, as relações de poder e a questão da Justiça na polis.

Em As Suplicantes, o coro de Danaides, aportadas em Argos, invoca primeiro Zeus Suplicante, e depois, os pátrios Numes - cuja categoria in- 
clui tanto os Deuses supremos quanto os mortos venerados como heróis locais - e terceiro Zeus Salvador. A prece a Zeus se desdobra na súplica ao rei Pelasgo e na interlocução indireta, mediada pelo rei Pelasgo, com o povo argivo. A prece e a súplica recorrem à persuasão violenta (cf. $A g$. 385), que parece - e é - chantagem e coação tanto a Zeus Olímpio quanto ao rei Pelasgo e a seu povo. No entanto, no exercício mesmo dessa persuasão pelas Danaides manifesta-se fatídica tensão conflituosa entre os interesses de Ártemis e os de Afrodite.

\section{As recém-chegadas e sua velada ameaça}

A invocação a "Zeus Suplicante" (Zeùs mén Aphíktōr), com que o coro abre o drama, transporta desde já o coro mesmo, e os espectadores do teatro de Dioniso, para o âmbito em que a ação dramática se desenvolve, ou seja, o da súplica e das injunções que, para o pensamento mítico grego, a súplica traz consigo.

Uma inscrição em Esparta atesta o epíteto cultual de Zeus Hikésios, com o mesmo sentido de "Suplicante" que Aphíktor, o qual parece ser uma criação de Ésquilo, num jogo etimológico com aphikoímetha ("suplicaríamos" Supp. 20), hiketôn ("súplices", Supp. 210) e ainda com aphiktóron ("suplicantes" Supp. 241) e aphíxeos ("súplica” Supp. 483), termos com que se descrevem a situação e a atitude do coro.

O título mesmo deste drama Hikétides significa ao mesmo tempo "recém-chegadas" e "suplicantes", tal como no verbo hiknéomai, ou, acrescentado o prefixo, aph-iknéomai, coincidem as acepções de "chegar" e de "suplicar". Esses termos descrevem a situação de despossuídos e desterrados que ao chegar suplicam por acolhida e abrigo, em nome de Zeus Hikésios, sob cuja proteção se põem. A atribuição do epíteto hikésios (ou seu equivalente poético aphíktor) a Zeus assinala que esses desvalidos pertencem a Zeus e, portanto, ao defrontar-se com um deles, defronta-se por meio desse com Zeus mesmo. Muitos documentos literários da época clássica, em versos e em prosa, atestam a gravidade e temeridade que constitui recusar-se a dar acolhida a tais súplicas, pois assim se incorre na cólera e no desfavor dos Deuses, sobretudo de Zeus Suplicante. Entre esses documentos, conta-se esta tragédia de Ésquilo.

Com vestes estranhas à indumentária grega, e portando ramos enfeitados de lã branca à maneira de suplicantes, o coro declara ter vindo do estuário do Nilo (Supp. 2-4). O nome "Egito" neste drama é reservado ao pai dos pretendentes perseguidores das Danaides, irmão de Dânao; e o país do rio Nilo é designado com perífrase "terra de Zeus contígua à 
Síria", dado o sincretismo entre Zeus e Ámon, cujo oráculo era célebre. Descrevendo-se como fugitivas (pheúgomen, "estamos em fuga", Supp. 5), o coro esclarece que não se trata de um exílio imposto como sanção de homicídio, mas conseqüente da alternativa escolhida contra as núpcias indesejadas. A referência ao "pai Dânao" (Supp. 11) completa a identificação da personalidade coletiva do coro como Danaides, o que dá à anterior menção ao não cometido homicídio o caráter de uma premonição, pois é sabido que as Danaides, na noite de suas núpcias, com punhais escondidos nas vestes, matam os seus maridos, exceto uma delas, Hipermnestra, que poupa o marido pelo desejo de ter filhos.

Não se esclarecerá, ao longo de todo o drama, se as núpcias são indesejadas por si mesmas, ou se os indesejados são esses pretendentes; no primeiro caso, haveria desdém e ofensa à Deusa Afrodite, cujo âmbito é o da sedução amorosa e do desejo; no segundo caso, apenas uma injunção política, em que esses pretendentes são rejeitados. Tanto na Grécia quanto no Egito é lícito o casamento entre primos de primeiro grau. Portanto, o adjetivo "ímpio" (asebê, Supp. 9) deve qualificar a atitude dos filhos de Egito não por pretenderem o casamento com primas, mas por obstinaremse numa pretensão contrária ao desejo das pretendidas e do pai delas. Embora permaneça ambíguo e indeciso se as Danaides rejeitam a união amorosa em si mesma, em princípio (o que implica ofensa a Afrodite), ou se apenas rejeitam casarem-se com esses seus primos. No entanto, tanto a apresentação de Dânao como "guia do conselho, guia do dissídio" (Supp. 11-2), quanto sua oposição a essa união de suas filhas com os primos delas, parecem favorecer a conjectura de que essa resistência ao casamento se deve a uma injunção política.

Declarado donde e por que partiu, o coro se volta para a terra aonde chegaram e por que a elegeram: nomeia, então, a terra argiva como origem de sua família por ser pátria de sua ancestral Io. Evocada na imagem da "aguilhoada novilha" (oistrodónou / bóos, Supp. 16-7), milagrosamente fecundada "ao sopro e ao toque de Zeus" (Supp. 17-8), a lembrança de Io revela um vínculo de consangüinidade entre as recém-chegadas e a terra a que chegam e assim impõe a esta terra o imperioso dever da benevolente acolhida.

Essa imposição se assinala no jogo de palavras pelo qual os "ramos coroados de lã" (Supp. 22) - insígnias que distinguem entre os gregos a condição de suplicante - se descrevem como "súplices punhais" (hiketôn enkheiridiois, Supp. 21), dado que a palavra enkheirídion significa "manual", tanto no sentido de "o que se traz na mão", quanto no de "punhal". Assim, o emblema da condição de suplicantes, sinal de fragilidade e de 
precariedade, transfigura-se numa arma mortal, com que se coagirá o rei de Argos.

Declaradas descendentes de Io, a antiga princesa de Argos, as recémchegadas invocam os "pátrios Numes de Argos" (Supp. 22a). Segundo M.L.West, - que com sua ciência ecdótica quase divinatória restaurou o verso Supp. 22a, - os "pátrios Numes" se dizem os Deuses locais, que presidem a comunidade, a terra e as águas vivíficas, designação genérica que abarca duas categorias distintas, a saber: os "Deuses supremos" (hýpatoi Theoí, Supp. 24), identificáveis com os Deuses Olímpios pan-helênicos, e os heróis locais, que não são Deuses, mas que aos Deuses se associam como protetores da cidade, "severos ao punir, subterrâneos ocupantes de sepulcros" (Supp. 24-5). Após essas duas categorias, "Zeus Salvador" mantém a sua posição de "terceiro" (Zeùs Sotèr trítos, Supp. 26), como na ordem ritual das libações, em que se invocam os Olímpios, os heróis e Zeus Sotér ("Salvador"). O epíteto de Zeus Sotér aí se explica pela função de "guarda-casa de varões pios" (Supp. 26-7), implicando que a salvação das casas dos argivos se condiciona ao piedoso acolhimento concedido por eles às recém-chegadas.

A contraposição entre o masculino e o feminino se delineia na oposição entre "a súplice / feminina expedição" (Supp.27-8), para a qual se pede acolhida "com o reverente vento do região" (Supp. 28-9), e o "masculino / bando transgressor" (Supp. 29-30), contra o qual se impreca que pereça de encontro a "tormenta / tempestuosa, trovão e relâmpago / e os ventos do selvagem / mar" (Supp. 33-6). Motivo alegado de tão odiosa imprecação: usurpação do poder que cabe ao tio paterno deles (patradélpheian, Supp. 38) e coerção a núpcias.

\section{A ameaça revelada}

Durante sua marcha, pela entrada lateral (párodo), até a pista de dança (orquestra), o canto do coro revela a sua origem, os seus motivos e a sua condição, e impreca contra os seus perseguidores (Supp. 1-39). Uma vez instalado na orquestra, o coro modula o seu canto em cinco pares de estrofe-antístrofe, seguidos de mais três pares nos quais um novo refrão se incrusta após cada estrofe e ecoa após cada antístrofe (Supp. 40-175).

Na primeira estrofe, a invocação do "vitelo de Zeus" (Supp. 41) instaura o vínculo das recém-chegadas com o lugar aonde chegam, ao mostrar o elo entre esta Argos e a sua originária "terra de Zeus" (i.e. o Egito, Supp. 4-5), sugerindo ainda a identificação entre Épafo - que aqui se designa como "vitelo de Zeus" - e o Deus bovino egípcio Ápis. 
Na tragédia Prometeu Cadeeiro de Ésquilo, a genealogia e a saga das Danaides é resumida na fala divinatória de Prometeu à errante princesa originária de Argos, Io, transmutada em novilha, ancestral das Danaides (Pr. 846-64):

Canopo é a cidade extrema da terra, junto à foz mesma e aluvião do Nilo, aí é que Zeus te faz boa de espírito, ao tocar com plácida mão e só tocar. Nomeado pela paternidade de Zeus, terás o negro Épafo, que colherá quanto o largífluo Nilo rega a terra. Cinco gerações depois, cinqüenta filhas virão outra vez a Argos, a contragosto, fêmeas sementes a fugir de congêneres núpcias com primos; mas eles, aturdidos, falcões deixados não longe das pombas, chegarão, caçadores de não caçáveis núpcias. Deus terá ciúmes dos corpos. Fêmeo Ares letal molhará terra pelásgia com os mortos por noctivígil audácia, pois cada mulher massacrará o marido, tingindo na garganta a bigúmea espada. Assim seja Cípris para meus inimigos.

Engendrado pelo toque de Zeus, e nomeado segundo essa circunstância, Épafo (cujo nome em grego soa como "Táctil", "Toque" ou “Tocado") nasceu no estuário do Nilo, donde depois suas descendentes Danaides partiram em fuga. O sincretismo entre Ápis e Épafo é reconhecido em Heródoto: "Ápis, a quem os gregos chamam Épafo" (Hdt. 3.27.1), e talvez se explique pela semelhança do mito do nascimento de ambos: "Este Ápis ou Épafo é um novilho nascido de uma vaca que não pode gerar nunca mais nova cria. Os egípcios contam que um raio baixa do céu sobre ela, que desse raio concebe Ápis." (Hdt. 3.28.2)․․ A Épafo cabe, pois, o epíteto "ultramarino defensor", que lhe conferem as Danaides ao invocá-lo em Argos (Supp. 41).

Na primeira antístrofe, “os antigos males" (Supp. 51) são as pretéritas aflições de Io, "prístina mãe" (Supp. 50), que as Danaides pretendem rememorar como indícios fiéis e confiáveis de seu vínculo de consangüinidade delas com os argivos.

\footnotetext{
${ }^{1}$ Tradução Maria de Fátima Silva e Cristina Abranches.
} 
Na segunda estrofe, no entanto, não mais as dores de Io, mas sim o lamento por suas próprias aflições elas dizem soar em sua voz. Ao ouvi-las, um áugure nativo da região - conhecedor da arte de adivinhar por meio da interpretação dos ruídos produzidos pelo comportamento dos pássaros - suporia ouvir a chorosa esposa de Tereu, transformada em rouxinol e entregue ao lastimoso gorjeio de suas misérias. Há dois motivos para essa sobreposição das figuras das Danaides e da esposa de Tereu: primeiro, a imagem do "rouxinol perseguido por falcão" (Supp. 62), com que elas próprias descrevem a si mesmas e aos seus primos que as perseguem, e segundo, o homicídio perpetrado contra familiares, que, no caso das Danaides, ao chegarem a Argos, somente um áugure poderia adivinhar (cf. Pr. 855-63). - Conta a lenda, recolhida por mitógrafos, que o rei trácio Tereu desposa Procne, filha de Pandíon, rei de Atenas, e tem com ela o filho Ítis, mas, desejando Filomela, irmã de Procne, viola-a e, para ocultar o crime, corta-lhe a língua. Procne, ao descobri-lo, mata Ítis para punir o crime do marido e dá-lhe de comer a carne do filho. Ao saber disso, Tereu persegue as irmãs, mas, antes de alcançá-las, os Deuses os transformam em pássaros: Tereu em falcão, Procne em rouxinol, e Filomela em andorinha, de modo que a perseguição prossegue, em novas formas transmutadas, e Procne, como rouxinol, pranteia a sorte do filho, ao gorjear "Ítis! Ítis!".

A segunda antístrofe explicita a sina e a situação de (Procne-)rouxinol, que ao ser expulsa de toda parte, e ao lamentar a perda dos logradouros habituais, compõe o relato da sorte do filho, morto sob a cólera da mãe mesma (Supp. 63-7). Assim, Danaides e Procne, vítimas da violência masculina, têm em comum a perseguição por falcões, o exílio forçado e o pranto. A reiteração de "lamento" (oîkton, Supp. 59/64) e de "lamentosa" / "lastimosa" (oiktrâs / philódyrtos, Supp. 61/68) ressalta o que há em comum nessas duas sinas e situações. A resposta à violência masculina com a matança perpetrada contra os laços de parentesco completará, no porvir das Danaides, essa comunidade de sinas.

A terceira estrofe retoma a descrição da figura das Danaides e suas circunstâncias: "lastimosa em cantos iônios" (philódyrtos Iaoníoisi nomoîsi, Supp. 69). Ante os termos Iaoníoisi nomoîsi, os editores hesitam e se dividem, uns grafando nómoisi ("cantos", "canções" - modo musical), outros, nomoîsi ("cantos", "cantões" - divisão territorial). Por sua vez, o adjetivo Iaoníoisi ("iônios") pode significar "iônios" em sentido restrito ou, por metonímia, "helênicos", e ainda - dada a etymología poética "de Io" (cf. Pr. 839-41). Portanto, nessa descrição se sobrepõem estas três alusões: elas lastimam $\left(1^{\circ}\right.$.) em cantos ao modo iônio, $\left(2^{\circ}\right.$.) não mais junto ao Nilo, mas na Grécia, $\left(3^{\circ}\right.$.) "nos relvosos prados da prístina mãe", i.e. de 
Io (cf. Supp. 50). Sendo tanta a aflição, laceram-se as faces com os gestos expressivos de dor, lacera-se o coração com os cuidados imponderáveis (Supp. 70-1). Quem mostrará amizade e prestará socorro a estas exiladas de uma terra invisível, entre brumas? (Supp. 69-76)

Na terceira antístrofe, o coro se volta ao Deuses pátrios (Theoí genétai, Supp. 78), invocando-os como "vigilantes da justiça", e pede-lhes que frustrem as pretensões de núpcias dos Egipcíades, uma vez que estas são transgressivas, e a transgressão (hýbrin, Supp. 81) causa horror aos Deuses. Este pedido ainda se justifica pelo venerando caráter de asilo e de abrigo que se atribui ao altar, em cuja proximidade - física e simbólica - o coro se situa (Supp. 83-5).

O que se pede aos Deuses pátrios formula-se como um voto que se espera de Zeus: "Por Zeus, bem seja, deveras!" (Supp. 86), a saber, que os perseguidores se percam, punidos, e cesse toda perseguição. Uma reflexão teológica, elaborada mediante a combinação de muitas imagens, parece sustentar essa esperança posta em Zeus (Supp. 87-103). Ante a evidência e iminência de que se possa consumar o intento dos Egipcíades, apela-se para a imprevisibilidade dos impenetráveis desígnios de Zeus, cujos caminhos não se deixam adivinhar, sombrios e inextricáveis (Supp. 87-90). Entretanto, o assentimento de Zeus é o penhor de que se preserve como possibilidade e por fim se dê a vitória perfeita: quando cair de costas significa perder a luta, assistido por esse assentimento, o contendente "cai firme, não de costas" (Supp. 91); e ao levar a desgraça a quem desassiste, a eficácia desse assentimento brilha através dos mais secretos sigilos e "fulgura / até nas trevas" (Supp. 94-5). Quando o orgulho dos mortais se ergue como torres, é dessas altas esperanças que se crêem tão sólidas que o Deus os precipita, sem nenhuma ostentação nem esforço algum, mas pelo único recurso de seus próprios desígnios (Supp. 96-103).

Na quinta antístrofe, concluído o excurso teológico, o coro retorna às suas circunstâncias, para encontrar nelas o exemplo concreto do que o excurso previa: a transgressão (hýbrin, Supp.104), como o tronco que se renova, nutrido de espírito imprudente, por furioso intento, sob o aguilhão do desejo das núpcias, conduz à erronia (átai, Supp. 110). Desse furioso intento, os transgressores são sujeitos pacientes, porquanto "furioso intento" (diánoian mainólin, Supp.109) constitui-se de ilusão e de logro (apátan, $S u, 111$ ), em que Zeus os enreda, de modo a levá-los à erronia. Na palavra "erronia" (átai/áte), condensam-se os sentidos de delírio, ação delirante e conseqüente ruína.

No entanto, muito aquém dessa doutrina teológica, a presente situação do coro permanece feita de incerteza. Na sexta estrofe, abatido pela 
incerteza e perplexidade, o coro funde as dores ao canto, ao descrever as “dores" (páthea, Supp. 112) como "estrídulas" (ligéa, Supp. 113) e "próprias ao canto lúgubre" (Supp. 115). Essa hipálage culmina no oximoro, quando o canto se torna honras fúnebres prestadas em vida a si mesma (Supp. 116). Ao dizer que celebra as próprias exéquias, o coro configura uma disposição de espírito, da qual deu o primeiro sinal ao exprimir sua dor com a laceração das faces - gesto peculiar ao rito do pranto funerário.

O primeiro estribilho - dito "efínio", de ephímnion, "o que se acrescenta (epí) ao hino (hýmnos)" - reitera a interlocução das recém-chegadas com a terra aonde chegam. Nesta interpelação de Apían boûnin ("alterosa Ápia”, Supp. 117) ressoa dupla alusão: primeira, ao Deus egípcio Ápis, identificado com o ancestral Épafo, e segunda, a Io, dita "novilha" (boûs, cf. boós, Supp. 42), dada a paronomásia entre boûs, "novilha" e boûnis, "alterosa", i.e. "colinosa", adjetivo do nome bounós, "colina". Assim a palavra mesma, como que à revelia de quem fala, invoca o vínculo ancestral entre as recém-chegadas e a terra a que chegam.

Na expressão karbâna d'audán ("voz peregrina", Supp. 119), H. Friis Johansen e Edward W. Whittle ${ }^{2}$ vêem um indício de que as Danaides são (representadas como) falantes de língua não-grega, pois sua comunicação sem embaraços com Pelasgo se deve à convenção poética de ignorar a diferença de línguas, a menos que haja algum propósito especial para mencioná-la.

A dilaceração de vestes caracteriza o pranto funerário: assim agem as coéforas junto ao túmulo do herói Agamêmnon (cf. Ch. 27-8), as mulheres persas no tenebroso luto ao saberem da morte de seus maridos na guerra (cf. Pers. 124; 536-8), e também o rei Xerxes, enlutado pela derrota e massacre de sua poderosa esquadra (cf. Pe. 835-6). Quando as Danaides esboçam a laceração de suas vestes (Supp. 120-1 = 131-2), insistem tacitamente no sentimento já manifesto de que fazem as suas próprias honras fúnebres - e o primeiro estribilho por si só ecoa essa insistência.

Na sexta estrofe, porém, novo apelo aos Deuses argumenta que a preservação da vida dos cultores é do interesse dos Deuses, visto que disso dependem oferendas e honras prestadas nos cultos (Supp. 123-4), alternando perplexidade (“Iò, ió, ió, indiscerníveis dores”, Supp. 125-6) e incerteza ("aonde levará esta onda?", Supp. 127).

Essa incerteza, figurada na imagem da onda, que não se sabe aonde levará (kûm', Supp. 127), aplaca-se com a lembrança, suscitada pela mesma metáfora da onda, de que a viagem por mar até Argos foi tranqüila, o que por si só constitui um sinal favorável para o porvir. Assim en-

${ }^{2}$ Aeschylus. The Suppliants, 3 v., Copenhagem, Gyldendalske, 1970. 
corajadas, as Danaides esperam e fazem votos de que o favor divino possa estender-se até a consecução dos propósitos dessa travessia bem-sucedida; e invocam Zeus "pai onividente" (Supp. 139), cuja providência então as assistiu e assim possa assisti-las no porvir. No segundo estribilho (Supp. 141-2 = 151-3) explicita-se o "término propício", que se pede a Zeus, como o êxito feliz na fuga dos perseguidores e das núpcias coercitivas. Quando as Danaides se referem a si mesma como "grande prole de augusta mãe" (i.e., de Io), ao dizerem então "pai onividente", invocam Zeus não só no sentido universal de "Pai dos Deuses e homens", mas - particularmente - pai fundador de sua linhagem.

Na sétima antístrofe, o poliptoto thélousa d'aû thélousan ("cuidadosa de meus cuidados" Supp.144) estabelece a identificação e o contraste entre Danaides, que invocam, e Ártemis, que é invocada, bem como entre Ártemis, que contempla, e Danaides, que são contempladas. A identificação, dada pela identidade dos cuidados, reitera-se nos termos da invocação (Diòs kóra, "filha de Zeus" Supp. 145), com que as Danaides reivindicam para si tanto a paternidade ancestral de Zeus, quanto a condição de virgem (ádmetos admétai, Supp. 149), já que elas, enquanto virgens perseguidas, esperam a aliança defensiva da Deusa virgem - Ártemis. Por outro lado, o contraste ainda se dá quando - exiladas à procura de asilo - invocam a Deusa "bem instalada em sacro templo" (ékhousa sémn' enópi’ asphalés, Supp.146).

O segundo estribilho ecoa, após a invocação a Ártemis, como após a invocação a Zeus, o mesmo pedido por êxito feliz na fuga de perseguidores e de núpcias coercitivas (Supp. 151-3).

A oitava e última estrofe considera a possibilidade de esse pedido não ter acolhida, junto aos Deuses Olímpios, especialmente junto a Zeus. A velada ameaça, em que ramos coroados de lã empunhados pelas suplicantes se diziam "súplices punhais" (hiketôn enkheiridiois, Supp. 21), afinal se revela: as suplicantes ameaçam transformar a súplica a Zeus "Súplice" (Aphiktor, Supp. 1) em súplica ao "térreo / hospitaleiro de muitos / Zeus dos defuntos" (Supp. 156-8), usando laços para se enforcarem.

O Deus Hades, cujos domínios são as sombras subterrâneas onde se confinam as sombras ou espectros dos mortos, é muitas vezes descrito com os epítetos polydéktes ou polydégmon ("acolhedor de muitos"), e muitas vezes chamado Zeus katakhthónios ("Subterrâneo"), ou simplesmente Zeus khthónios ("Térreo"). Dada a equivalência entre os nomes khthón e gaîa como designação do solo e da terra, o epíteto "térreo" (gáion, Supp.156) é um claro equivalente de khthónios ou katakhthónios, e o epíteto "hospitaleiro de muitos" (polyxenótaton, Supp.157) claramente joga com o epíteto de Zeus "Hóspede" (Xênios, cf. Supp. 627). Se o seu pedido 
não lograr a acolhida de Zeus, as suplicantes certamente terão, mortas, a acolhida de Hades, acolhedor de muitos (Supp. 154-61).

No terceiro e último estribilho, a invocação a Zeus se associa ao lamento da ira contra Io: â Zen, Ioûs iò mênis ("Â, Zeus! Iò, ira contra Io", Supp. 162). A paronomásia Ioûs iò sugere a ominosa etimologia que vincula o nome de Io à interjeição de dor ió (cf. Pr. 694-5). A "ira contra Io" é atribuída a "Deuses" em geral (ek Theôn, Supp.163), mas recebe uma surpreendente qualificação: másteir' (“víndice”, Supp. 164). Ora, máster - donde a forma feminina másteira - designa em Atenas o magistrado incumbido de averiguar e confiscar o patrimônio e espólio de proscritos e de endividados com o poder público. A Deusa Hera, cujo domínio é o do patrimônio familiar e do casamento como instituição social, não é mencionada, mas aludida como esposa cuja cólera é vencedora no céu (Supp. 164-5). Essa alusão ao domínio e ao poder de Hera sugere que se compreenda o malogro das suplicantes como a extensão do ressentimento de Hera aos descendentes de Io. Essa sugestão se condensa na metáfora do último verso do estribilho: "de áspero vento vem tempestade" (Supp.166).

Contra esse possível malogro de seu pedido junto a Zeus, as suplicantes brandem contra Zeus mesmo uma ameaça: caso não acolha essa prece de seus descendentes, estará sujeito à justa acusação de não honrar o filho que outrora ele mesmo gerou, o filho da novilha (Supp. 168-75).

\section{Guia do conselho, guia do dissídio.}

A figura de Dânao - pai guia do conselho e guia do dissídio (Danaòs dé, patér kaì boúlarkhos kaì stasíarkhos, Supp. 11) - abre e domina a primeira cena do primeiro episódio. Piloto veterano e confiável que com prudência conduziu as filhas sobre o mar, exige delas prudência igual à sua como condição para levar a bom termo a aventura sobre a terra firme. Anuncia a aproximação da multidão armada de escudo e lança, prenunciada pela poeira e pelo chiado dos eixos dos carros. Prevê que sejam líderes locais que, informados por mensageiros, venham observar e verificar quem são os recém-chegados, e por ser impossível saber previamente se vêm com disposição hostil ou hospitaleira, aconselha às filhas que busquem asilo na colina junto ao altar dos Deuses, de modo a serem vistas como suplicantes desses Deuses e sob a guarda deles.

Aparentemente Dânao está instalado na colina, que lhe serve de mirante. Não há indícios se ele entrou junto com o coro no primeiro verso, ou depois de executado o primeiro canto coral; nem há menção anterior a essa colina. Templos, altares e santuários tradicionalmente servem de 
asilo e tornam inviolável quem se declara suplicante dos Deuses aos quais estão consagrados. A esse expediente é que Dânao aconselha as filhas a recorrerem, e dá instruções sobre o procedimento e o uso da palavra convenientes à situação: levarem na mão esquerda os ramos adornados com lã como oferenda a Zeus Reverente, de modo a deixar a mão direita livre para estender-se no gesto de súplica; serem comedidas nas palavras e nas atitudes, de modo a suscitar benevolência e boa acolhida. O epíteto "Reverente" cabe a Zeus (aidoiou Diós, Supp.192), bem como o epíteto "Suplicante" (Aphíktor, Supp. 1), porque a atitude e a situação dos suplicantes implicam e configuram a interlocução com Zeus, de modo que tanto a súplica dos desvalidos, quanto a reverência dos que lhes valem, necessariamente participam do favor divino.

O corifeu, ao acolher os conselhos de seu pai Dânao e ao comprometer-se a observá-los e conservar-lhes a lembrança, pede pela vigilância de "Zeus Pátrio" (Zeùs dè gennétor ídoi, Supp. 204). Neste epíteto de "Zeus Pátrio", ressoa não somente a piedade filial com que se aceitam e guardam os conselhos paternos, mas ainda a reivindicação da ancestralidade a remontar a Zeus mesmo, e sobretudo o pressuposto (já anunciado nos versos 168-74) de que o Deus - por ser honrado - deve honrar sua descendência com sua vigilância e proteção.

Na breve esticomitia (Supp. 207-21), enquanto o coro se dirige à colina e ao altar comum dos Deuses, Dânao distingue e indica ao corifeu alguns Deuses que devem ser invocados. Supõe-se que, tal como na ágora de Atenas contemporânea de Ésquilo, os doze Deuses estivessem representados nesse altar comum com doze estátuas de madeira (brétea, Supp. 463), pois o culto dos doze Deuses era muito difundido na Grécia antiga e, além disso, numa cena seguinte, o coro - composto de doze coristas - faz ao rei Pelasgo a terrível ameaça de enforcarem-se com os cintos nas estátuas dos Deuses (Supp. 463-5).

Dânao primeiro se refere a Apolo como "o filho de Zeus" (Zenòs înin, Su 212). Em vez de înin, "filho", os manuscritos trazem órnin, "pássaro"; ora, o pássaro de Zeus é a águia, mas como não se entenderia bem porque invocar águia entre Deuses, alguns editores adotaram a lição Zenòs înin, "o filho de Zeus". Apolo, nesse verso, como alhures, é identificado com os raios do sol, e distinguido por dois traços que justificariam sua vinculação à causa das Danaides: $1^{\circ}$ ) o epíteto "puro" e $2^{\circ}$ ) o mitologema do "Deus exilado do céu" (hagnón ... phygád' ap' ouranoû Theón, Supp. 214). O epíteto "puro", comum a Apolo e a Ártemis, assinala a estrita e exclusiva pertinência das atribuições desses Deuses, e condiz com a condição etária e social de virgens inuptas (e refratárias a núpcias) das Danaides. 
A qualificação do Deus como "exilado do céu" cria um oximoro com a identificação entre Apolo e os raios do sol, mas ressalta uma situação comum ao Deus e às Danaides, exiladas e suplicantes. No prólogo de Alceste de Eurípides, o exílio de Apolo junto ao palácio de Admeto é explicado como punição por Apolo ter matado os Ciclopes, fabricantes do raio de Zeus, furioso por que Zeus fulminou o seu filho Asclépio. As Danaides esperam que a sina comum do exílio suscite a compaixão de Apolo.

Posídon não é nomeado, mas indicado e invocado por seu signo, o tridente, porque bem conduziu os foragidos no mar, e para que bem os receba em terra firme (Supp. 218-9).

Hermes fecha a enumeração dos Deuses e a esticomitia, invocado como arauto, para que enuncie boa notícia que possa conferir às suplicantes a condição de livres.

Dânao resume seus conselhos às filhas, antes de elas se encontrarem com o rei Pelasgo, com a exortação à veneração ante o altar comum de todos os Deuses. Descrevendo-as como "bando de pombas" e aos seus perseguidores como "gaviões", ressalta a enormidade do comportamento deles com o oximoro: "hostis aos consangüíneos" (ekhthrôn homaímois, Supp. 225). O vínculo da consangüinidade é a forma mais própria da philía, ou seja, o modo mais estreito e natural de participação na comunidade familiar; ser inimigo da própria família é uma violação desses laços sagrados; assim, o oximoro se desdobra e se explica como "poluentes da casa" (kaì miainónton génos, Supp. 225). A impiedade e poluência reside na coerção com que se impõem as núpcias indesejadas e forçadas. Nessa fala de Dânao, retoma-se uma noção de justiça que vê no Hades um outro Zeus como juiz póstumo, diante do qual nem a morte extingue a exigência de punição dos transgressores (cf. Eu. 273-5).

\section{Pelasgo, filho do terrígeno Palécton}

O rei Pelasgo surpreende-se com o grupo de mulheres, vestidas e adornadas de modo estranho aos costumes gregos, que ousou chegar à região sem arautos nem guias e, portanto, também sem quem lhe patrocinasse a vinda. Aparentemente, o rei somente toma conhecimento da presença de Dânao, quando o corifeu a ele se refere e aponta como "este meu pai” (toûd' emô̂ patrós, Su, 319). De imediato, no entanto, percebe que se trata de suplicantes, não só pelos ramos que elas seguram, mas também os que elas depositaram sobre o altar. Sendo essa atitude e essas insígnias de suplicantes o único traço que trai origem grega nesse grupo, o rei espera que as recém-chegadas declarem quem são. 
O corifeu reverte essa expectativa, ao perguntar pela posição social de quem o interpela. O rei, cuja aparência não o distingue claramente como tal, deve, então, antes declarar quem é e, ao fazê-lo, desdobra sua explicação em duas partes justapostas: uma referente ao seu nome e ao seu domínio (Supp. 250-9), e outra referente ao nome da região e às circunstâncias dessa nomeação (Supp.260-70). Sabemos assim que o rei Pelasgo, em razão de sua realeza mesma dá nome ao seu povo, os pelasgos, e que é filho de Palécton, cujo nome significa algo como "antigo solo" e condiz com a alegada autoctonia de "nascido da terra" (gegenoûs, "terrígeno", Supp. 250); o domínio de Pelasgo é muito mais extenso que a Argos histórica e encerra vasta extensão da Grécia continental. Sabemos também que a região de Argos se chama Ápia em razão do herói Ápis, médico-adivinho filho de Apolo, que ao chegar deu remédio e expurgou a região das monstruosas e homicidas serpentes produzidas pela poluência gerada por antigo crime cruento.

As Danaides, ao chegarem a Argos, de certo modo reiteram a situação em Argos à chegada de Ápis: enquanto o médico-adivinho deu remédios (áke, Supp. 268) saneadores de hostil multidão de serpentes (drakonthómilon dysmenê, Supp.267), elas criam a necessidade de demanda por remédios (áke, Supp. 367, 451), ao chegarem perseguidas por serpentes hostis (drakónton dysphrónon, Supp. 511). Entretanto, ao contrário do herói epônimo Ápis, que tem origem celeste, filho de um Deus celeste, o rei epônimo Pelasgo tem origem ctônica, filho do terrígeno Palécton, o que parece prefigurar para o rei um destino inverso ao do herói.

Atendendo à exigência de brevidade ao falar, feita pelo rei tendo em vista o gosto de seus concidadãos argivos (tão lacônicos quanto os espartanos, embora o rei mesmo não se tenha mostrado tão lacônico assim), as Danaides proclamam sua origem com breve e clara palavra: "origem argiva... prole de nobre novilha" (Supp.274-5).

Essa revelação parece menos surpreendente (ou, menos convincente) que a aparência e presença mesma das forasteiras em Argos, pois o rei continua a conjeturar, preso à figura delas, atinando que se parecem mais com as mulheres líbias que com as argivas. Líbia é o nome da filha de Épafo, avó das Danaides (cf. Supp. 317-9); esse nome, desde os poemas homéricos, designa também a região do Egito, sendo por vezes extensivo à África inteira. A conjectura do rei, correta, formula-se com mais precisão na metáfora da planta nutrida pelo rio Nilo (Supp. 281), e enlaça-se com outras evocações, cuja força simbólica não deixa de ser verdadeira, ao mencionar as Amazonas, "sem marido e carnívoras" (Supp. 287). Pelasgo, por fim, retoma as palavras do corifeu, interrogando-o sobre a declarada origem argiva. 
O corifeu propõe, como fundamento de sua declarada origem, o fato, transmitido e reconhecido pela tradição (e, também, pelo rei), de que Io em Argos foi sacerdotisa guardiã do templo de Hera (Supp. 291-3). Sobre esse fato, na esticomitia que segue (Supp. 291-324), o rei faz uma série de perguntas ao corifeu, pondo à prova o conhecimento e a coerência deste a respeito de sua declarada origem. Neste caso, o conhecimento mesmo, pela clareza, coerência e convicção com que se apresenta, serve de instrumento de identificação de quem o traz consigo, à maneira de uma senha ou de um sýmbolon.

Na primeira questão formulada pelo rei ("Não dizem ainda Zeus ter amado mortal?", Supp. 295), a referência a Io como "mortal" (brotôi) contrasta a sua condição humana não somente com a natureza divina de seu amante, mas também com a sua posterior metamorfose em novilha, e implica ainda que sua união com Zeus se deu em Argos, o que é relevante para a reivindicação de origem argiva pelas Danaides.

O reconhecimento da amplitude do poder exercido pela Deusa Hera, assinalado no título comum a ambos, Zeus e Hera, "dois reis" (basileoin, Supp. 298), reitera a doutrina do último efínio do párodo (Supp.162-6):
$\hat{A}$, Zeus! Iò, ira contra Io, víndice, vinda de Deuses!
Conheço a cólera
da esposa: no céu ela vence,
de áspero vento vem tempestade.

Nesse efínio, a enormidade dos sofrimentos de Io é atribuída à cólera e ao poder vitorioso de Hera, mencionada apenas pelo título de "esposa" (gametâs, Supp. 165): tanto o jogo etimológico entre a interjeição de dor ió e o nome de Io, quanto o epíteto qualificativo da "cólera da esposa" ouranónikon (“celivictriz", i.e. "no céu ela vence", Supp. 165), explicam a natureza e o âmbito dos sofrimentos de Io, pois eles se devem ao destino individual (ió/Ió) de ter ingressado no âmbito da Deusa Hera, a saber, o âmbito do matrimônio em que se gera a descendência e assim se perpetua a família.

$\mathrm{Na}$ esticomitia entre o rei e o corifeu, atribui-se à Deusa Hera, referida agora como "Deusa argiva" (Supp. 299), a autoria da metamorfose de Io em novilha. Por que "Deusa argiva", e por que "novilha"?

Ao reiterarem-se e ressaltarem-se o poder de Hera e o seu vínculo com Argos, a figura de Io é enaltecida e a reivindicação de origem argiva pelas Danaides se fortalece. O epíteto homérico de Hera boôpis, - que, segundo Pierre Chantraine, talvez na origem significasse "de cabeça de 
vaca", e finalmente, "de grandes olhos de vaca", - aponta, a meu ver, o mesmo campo semântico que "novilha" (boûn, Supp.299; boï, Su, 300, 303, 306; boós, Supp. 314; etc.), a saber, o da maternidade.

$\mathrm{O}$ mitologema de Io descreve as atribulações da moça em idade núbil, quando se consuma o casamento e ela se encontra no domínio de Hera. A união com Zeus é a entrega ao marido, as errâncias por países e povos exóticos são o abandono do lar paterno e as aflitivas incertezas do novo e ainda estranho lar: ao casar-se, a mulher grega se desligava de sua família mediante um rito próprio, e mediante um outro rito era admitida e integrada na família do marido. O nascimento do primeiro filho realizava o mais importante propósito do casamento antigo: a perpetuação da família, e por isso mesmo representava o fim das incertezas. O toque de Zeus, que libera o parto, faz também cessarem as errâncias; é a imposição de mão que, curativa e leniente, põe fim às aflições. Nesse confronto de atribulações, Argo, "onividente pastor de única rês" (Supp. 304), parece uma figuração da cerrada vigilância em que se vê a mulher recém-casada em sua nova situação e nova família.

A palavra mýopa (Supp. 302) tem duas acepções: "mutuca" e "aguilhão". Oîstron, que as Danaides dão como equivalente de mýopa entre os habitantes do Nilo (Supp. 308), também tem duas acepções: "mutuca" e, por metáfora, "ferroada", e ainda "desejo veemente", "frenesi”. Preferi traduzir mýopa por "aguilhão" e ô̂stron por "estro" (neste caso, aportuguesando o vocábulo grego, que mantém na forma vernácula o sentido metafórico do original). A meu ver, neste mitologema de Io, estas palavras mýopa e ô̂stron descrevem a força obsessiva e lancinante do desejo, como a imagem "o dardo do desejo" (himérou bélei, Pr. 644), que descreve o interesse de Zeus por Io.

Impelida pelo aguilhão do desejo, Io chega a Canopo, "junto à foz mesma e aluvião do Nilo" (Pr. 846), e a Mênfis, no interior, acima do Nilo (Supp. 311). Entretanto, novo sentido de Zeus se revela com o nascimento do primogênito, "ao tocar com plácida mão e só tocar" (Pr. 849): todo o passado se transfigura, cessam todas as errâncias e aflições, a concepção e o parto se resumem no simples toque de Zeus - "Tangedor" (Epháptor, Supp. 313): o filho, que consubstancia esse toque libertador, tem desse toque o seu ser e o seu nome: Épaphos - "Épafo, em verdade epônimo do toque" (Supp. 315, cf. Supp. 45-6 e Pr. 849-51). Duas palavras se sobrepõem na designação desse toque: em Supp. 45 éphapsis, que é simplesmente designativa da ação de tocar, e à qual a etimologia poética liga o antropônimo; e em Supp. 315, rhysion, que igualmente significa "toque", mas também "resgate", "o que se dá (ou: o que se tem) em compensação". 
Épafo é o resgate de tudo o que se perdeu e se foi na consumação do desejo e no frenesi, e traz consigo a renovação da vida.

Supõe-se que no verso omitido (Supp. 316) o rei Pelasgo perguntasse qual era a descendência de Épafo. Tendo indicado a sua progênie desde Io, nomeando Líbia, a filha de Épafo, e Belo, filho de Líbia e pai de Dânao e de Egito, incluindo-se entre as cinqüenta filhas de Dânao e mencionando os cinqüenta filhos de Egito, o corifeu crê que pudesse esperar do rei Pelasgo uma acolhida conforme essa declarada e comprovada origem argiva (Supp. 323-4). O rei, porém, parece muito cautelosamente admitir apenas uma antiga ligação entre estas recém-chegadas e a terra de Argos, e pede informações suplementares de como e por que chegaram a Argos.

Com respostas evasivas e alusivas, o corifeu no entanto deixa muito claro o que lhe convém: o seu pedido é por asilo, ou seja, que as não entreguem aos Egipcíades, se estes as reclamarem. Este pedido, claramente formulado diante dos altares da cidade cobertos de ramos coroados de lã, faz o rei estremecer, pois impõem-lhe um vínculo com Zeus Suplicante (Zenòs Hikesíou, Supp. 347).

\section{O rei e o dilema insolúvel}

O corifeu, interpelando o rei em tom solene de uma prece, como a um Deus ou a um herói, descreve a si mesmo comparando-se a uma novilha que, perseguida por lobos, busca abrigo num penhasco, donde com mugidos faz apelo ao pastor (Supp. 348-53). Este símile implica a equação em que as Danaides estão para a sua ancestral Io como os seus perseguidores Egipcíades para os lobos, e ainda como o penhasco, que abriga a novilha, está para o altar dos Deuses em Argos, onde elas depositaram os ramos súplices, e também como o rei Pelasgo, a quem elas se dirigem como em prece, está para o pastor a quem a novilha apela.

Se aceitamos o entendimento de Supp. 355 proposto por M.L.West ${ }^{3}$, que lê hómilon ("assembléia") em referência às Danaides, e não em referência aos "Deuses juntos" (agoníon Theôn), e se tomamos este assim entendido hómilon ("assembléia") como objeto do verbo principal horô ("vejo", Supp. 354), - a resposta do rei à interpelação do corifeu tem um caráter cortante, ao rejeitar as alusivas implicações do símile da novilha, e ao descrever a realidade posta sob seus olhos em termos de mais imediatas e de mais urgentes implicações, configuradas no medo de que - por causa dessas suplicantes - a cidade se torne presa de danoso conflito (Supp. 354-8).

\footnotetext{
Aeschylus. Supplices, Stuttgart, Teubner, 1992.
} 
O corifeu, então, reitera a sua prece com votos de que o exílio seja preservado de todo dano pela lei dos suplicantes, nascida de Zeus, que distribui e faz cumprirem-se as sortes. Acrescenta que a pureza, provada na reverente observação dessa lei de Zeus, é a condição propiciadora da graça e favor divinos (Supp. 359-64).

O rei alega que as suplicantes não se dirigiram a seu lar, mas sim a um altar público; portanto, se a pureza pode residir no acolhimento concedido a essa súplica, a eventual impureza decorrente dessa mesma súplica não concerne a ele, particularmente, mas sim a todo o povo, em conjunto. Não lhe cabe, pois, decidir sozinho, mas antes comunicar a todos o que diz respeito a todos. Em contrapartida, o corifeu argumenta que o rei mesmo é a cidade e o povo, e que, por não estar sujeito à qualquer prestação de contas, tem poder soberano sobre o altar, e no exercício desse poder absoluto deve evitar a poluência - que seria suscitada pela recusa ao que se pede em súplica. Essa descrição da realeza, que contrasta chocantemente com a democracia ateniense da época clássica, condiz com o exercício do poder real na época heróica, e o rei não pode negar a veracidade dessas palavras.

Os termos do dilema, em que o rei se vê preso, mostram-se com clareza (Supp. 378-80):

Não posso defender-vos sem dano, nem é prudente desprezar as preces. Perplexo, e pavor me toma o espírito, por agir e por não agir e pela sorte.

A impossibilidade real de agir para o rei Pelasgo provém da impossível escolha entre entrar em guerra e desprezar súplicas. O coro evoca o vigilante guardião, presente nas súplicas e nos suplicantes, e cuja cólera é implacável na execução da justiça punitiva: Zeus Suplicante (Zenòs hiktaíou kótos, Supp. 385).

O rei tenta uma saída pela interpretação da lei civil e do poder e da autoridade conferidos pela lei civil aos Egipcíades e concernentes à relação entre primos e primas. O coro responde a esse poder e autoridade da lei civil, contrapondo-lhes Justiça divina e veneração pelos Deuses.

Dilema por dilema, o do rei Pelasgo (ou repelir suplicantes, ou entrar em guerra Supp. 378-80) é similar ao da Deusa Palas Atena (ou repelir súplica de Orestes, ou entrar em guerra com Erínies, Eu. 470-81). A saída que o rei Pelasgo encontra é similar à encontrada pela Deusa Palas Atena, que escolhe juízes de homicídios na cidade e institui o tribunal 
do Areópago (Eu. 482-99): rei Pelasgo recorre à decisão da assembléia dos cidadãos argivos.

Ouvidas a evocações das suplicantes, antes de expor a questão a seus súditos (tratados como se fossem concidadãos), o rei reexamina o dilema, em termos agora já prestes a desfazê-lo, quando o exame revelar que a alternativa se dá entre termos desiguais, porque se dá como escolha entre "um conflito por resgate" (dêris rhysíon, Supp. 412) e "sem oblívio o destrutivo Deus / que nem no Hades deixa livre o morto" (Supp. 415-6).

No entanto a eminência quase imediata da guerra com mortais parece contrapesar a transcendência difusa da presença divina, e parece ao rei ainda pedir um "pensamento salvador" (phrontídos soteríou, Supp.416).

$\mathrm{O}$ coro então interpela o rei Pelasgos, apelando à sua participação em Zeus Súplice, ao pedir-lhe que com justiça fosse reverente patrono, e que as não visse resgatadas dos altares de muitos Deuses (ex hedrân polytheôn rhysiastheîsan, Supp. 424).

Nessa interpelação ao rei Pelasgos, o coro se dirige ao rei, como a Zeus, ao invocar: "ó tu, que tens todo o poder da terra" (Supp. 425). O que há em comum ao rei e a Zeus, é que ambos são testemunhas do que o coro descreve como "a transgressão de homens" (hýbrin anéron, Supp. 426), que seria resgatá-las, arrancando-as do asilo junto aos altares. Se essa transgressão provoca a cólera de Zeus, o rei deve manter-se contrário à transgressão, e assim evitar tanto incorrer na cólera quanto legar aos filhos e ao palácio uma dívida a pagar com Ares (Supp. 427-437).

\section{A ameaça reiterada}

O insolúvel dilema imobiliza o rei, porque lhe parece impossível escolher entre duas grandes guerras: ou a guerra eminente contra Egipcíades, ou a guerra insustentável contra Deuses presentes nestes altares (Supp. 438-50).

O corifeu tem um último argumento, com que o dilema se desfaz, quando se desigualam os dois termos da alternativa: a ameaça de suicídio coletivo, enforcadas junto às estatuas dos Deuses (Supp. 455-65). A poluência dessa morte seria insuportável e destrutiva para a cidade, os cidadãos, a região, os rebanhos e as colheitas.

Com esse argumento definitivo, a mesma ameaça de matar-se já feita a Zeus mesmo (Supp. 154-62), o corifeu logra persuadir o rei. Ainda que possa parecer um "inescrupuloso golpe de mestre" ("unescrupulous masterstroke' $)^{4}$, o corifeu não parece estar blefando, e o rei Pelasgo não

${ }^{4}$ H. Frits Johansen e E. Whitle, v. 2, p. 360. 
aposta nisso. Essa ameaça, feita ao rei, e essa mesma ameaça, feita a Zeus mesmo, parece constituir um recurso legítimo, ainda que nem sempre tão eficaz, na perspectiva da piedade grega antiga. Parece legítimo e piedoso tanto o uso que dele fazem as Danaides, quanto o uso que, segundo Heródoto (7.140-1), dele fizeram os atenienses durante a consulta ao oráculo de Apolo em Delfos, na eminência da invasão da Ática pelos persas, quando também os delegados atenienses ameaçaram a profetisa pítia e ao Deus Apolo, com as palavras: "Ó senhor, dá-nos melhor oráculo sobre nossa pátria, em respeito a estes ramos de suplicantes, com que aqui viemos, ou não sairemos do ádito, mas aqui permaneceremos até morrer." (Hdt. 7.141). Os acontecimentos conseqüentes dessas palavras, na narrativa de Heródoto, mostram que a atitude dos delegados atenienses era acertada, e que o Deus assim se deixou persuadir.

A súbita compreensão - de que, com a enigmática palavra: "adornar estas imagens com tábuas novas" (Supp. 463), as Danaides dizem simplesmente: "destes Deuses, rápido, enforcar-nos" (Supp. 465) - fustiga o coração do rei. Neste dilema entre a insuperável "poluência" (míasm', Supp. 473) e os "varões por mulheres ensangüentarem o chão" (Supp. 477), o rei Pelasgo reconhece o caráter da necessidade no temor à cólera de Zeus Suplicante (Zenòs... Hikteríou, Supp. 478-9).

Reconhecida, essa necessidade impõe ao rei a cooperação com a causa das Danaides, e assim ele se associa a Dânao nos cuidados para persuadir o povo de Argos a não rejeitar a fala do rei, que fala em favor de acolherem-se as suplicantes (Supp. 480-9).

Dânao declara ter encontrado no rei Pelasgo "reverente patrono" (aidoîon... próxenon, Supp. 491), e pede-lhe escolta de "guias e condutores nativos" (opáonas dè phrastorás t'egkhoríon, Supp. 492), para encontrar os altares dos Deuses guardiães da cidade, onde depositar os ramos de suplicantes, e para ter segurança, ao percorrer a cidade. Atendido, Dânao parte (Supp.500-4).

O rei Pelasgo dá instruções às Danaides, e assim tenta tranqüilizálas, reiterando seu comprometimento com a causa delas, e mostrando-se solidário com os sentimentos delas a respeito dos Egipcíades. Ao partir, alega que instruirá Dânao sobre como convém falar, e recomenda às suplicantes que façam preces aos Deuses locais (Supp. 506-23).

\section{A invocação a Zeus e Io}

A sós, o coro invoca a Zeus como o feliz fundamento de toda felicidade e de todo exercício de poder executivo, e pede-lhe que se deixe 
persuadir, que repila de sua família com horror a "soberba dos homens" (andrôn hýbrin, Supp. 528) e afunde nas águas cor de púrpura a "erronia de bancos negros" (melanózyg' átan, Supp. 530).

A acusação de ser "transgressor" (hybristés Supp. 30) e de cometer "transgressão" (hýbris, Supp. 81, 103, 426, 487, 528, 816, 881), imputada pelo corifeu e pelo coro coletivamente aos Egipcíades, provê à fuga das Danaides a aparente justificativa de evitar a violência de submeterem-se a núpcias indesejáveis e, ao associar "transgressão" a "erronia", prevê que inevitável punição há de se abater sobre o "transgressor".

A sombra de "erronia" (áte, Supp. 110, 164, 444, 470, 530, 850, 886) acompanha a "transgressão" de modo que, ao consumar-se a "transgressão", a sua face obscura de cegueira moral se revela como "erronia" e conseqüentemente se configura como ruína em que se precipita por um cego açodamento. Nesse caráter punitivo de "erronia" se manifesta a ação de Justiça divina, e assim "erronia" designa tanto um comportamento dos mortais quanto uma figuração do divino. Inter áte et Áte non semper distingui potest, "nem sempre é possível distinguir entre áte e Áte".

Na primeira estrofe do primeiro estásimo de As Suplicantes de Ésquilo, a relação entre Zeus - descrito como o feliz fundamento de toda felicidade e de todo exercício de poder executivo - e a "transgressão de homens" é mediada por “verdadeiro horror" (eu stygésas, Supp. 258), bem como a relação entre os Deuses pátrios e a transgressão é mediada por "verdadeiro horror" (etýmos stygoûntes, Supp. 81). Esse "horror" se diz "verdadeiro", tanto no sentido da causalidade e da eficácia (eu), quanto no sentido da realidade e da autenticidade (etýmos); em ambos os casos, o verbo stygeîn, "ter horror", evoca a noção do rio Estige (Stýx) - fronteira mítica entre o âmbito da participação de ser e o da privação de ser. Tanto o horror dos Deuses pátrios quanto o horror de Zeus causam essa revelação de "transgressão" - hýbris - como "erronia", "perdição" e "ruína" - áte / Áte. A hipálage que descreve "erronia" como "de bancos negros" (melanózyg’ átan, Supp. 530) resume a imprecação contra os Egipcíades, cujos barcos são evocados pelo epíteto “de bancos negros” (melanózyg'): Zeus os lance no mar cor de púrpura.

Na primeira antístrofe, com o mitologema de Io o coro apela à vigilância de Zeus pelas mulheres de sua legendária família, à amizade de Zeus por Io - mulher ancestral de sua família, à memória do toque libertador de Zeus em Io, e assim se evoca o vínculo de amizade ancestral entre Zeus e as Danaides (Supp. 531-7).

G. ItALIE, Index Aeschyleus, Leiden, Brill, 1964, sub uerba. 
O percurso de Io desde Argos até o Nilo se descreve, então, como se o reiterasse ao inverso o regresso das Danaides - "por antigo vestígio" (Supp. 538) - à pátria de sua ancestral Io, de modo que o término da fuga de Io com o toque libertador de Zeus possa prefigurar o término da fuga das Danaides com o renovado e renovador gesto de Zeus, ao acolher a prece dessas suplicantes junto aos argivos (Supp. 538-99).

\section{O decreto de Zeus}

Dânao retorna da assembléia do povo pelasgo para contar às filhas a sua versão do que lá viu e ouviu. Pela contagem das mãos direitas erguidas, persuadido pelos argumentos do rei Pelasgo, o povo aprovou por unanimidade o decreto que concede asilo às Danaides. Como Dânao vê o que move o rei Pelasgo e o povo pelasgo: por temor à grande ira de Zeus Súplice, o rei e o povo visam a evitar incorrer em dupla poluência, suscitada pela rejeição a súplicas de hóspedes que se apresentam como descendentes de ancestrais comuns. A aprovação do povo torna a proposta do rei um decreto, pois essa mesma aprovação do povo, dócil e unânime, assinala que o decreto de Zeus respalda os termos da proposta (Supp. 621-4):

Ao ouvi-lo, o povo argivo com as mãos decretou sem arauto que assim fosse.

O povo pelasgo ouviu dócil os volteios da fala ao povo, e Zeus decretou o termo.

\section{As preces das Danaides pelos argivos}

As preces das Danaides pelos argivos, no segundo estásimo de $A s$ Suplicantes de Ésquilo, aparentemente têm em comum, com as preces das Eumênides pelos atenienses, no último episódio de Eumênides, fiarem-se e fundarem-se na noção hesiódica de Justiça, filha de Zeus. Na Teogonia, essa noção se descreve mediante a imagem de núpcias e procriação (901-6):

Após desposou Têmis luzente que gerou as Horas, Eqüidade, Justiça e a Paz viçosa que cuidam dos campos dos perecíveis mortais, e as Partes a quem mais deu honra o sábio Zeus, Fiandeira, Distributriz e Inflexível que atribuem aos homens os haveres de bem e de mal. 
Zeus, unido a "Lei" (Thémis) em amor, gerou duas tríades: as "Horas" (Hórai) - "Eqüidade" (Eunomía), "Justiça" (Díke) e "Paz" (Eiréne) - e as "Partes" (Moîrai) - "Fiandeira" (Klothó), "Distributriz" (Lákhesis) e "Inflexível" (Átropos). O nome das "Horas", - que designa tanto as Deusas filhas de Zeus e Têmis, quanto as partes (estações) do ano, - se explica pelo verbo descritivo do que fazem: "cuidam dos campos" (érg'oreúousi, Th. 903) Os cuidados, com que as Horas cercam as lavouras dos morituros mortais, têm um sentido muito mais amplo, de observar as suas ações em geral (érg' Th. 903). O que hoje consensualmente distinguimos com nitidez entre fenômenos da ordem natural (as horas, as estações do ano, a passagem do tempo, a fecundidade do solo) e fenômenos do âmbito político-social (a eqüidade e com ela a consolidação das leis, a justiça e a paz social), o pensamento mítico apreende como uma unidade complexa, que reúne e integra aspectos fundamentais do mundo, nomeados com os nomes desses Deuses - Eqüidade, Justiça e Paz, - e simetricamente espelhados na tríade gemelar: as Deusas Partes, que presidem e constituem a participação de cada um em ser e ter, tanto entre os mortal quanto entre os imortal.

A justiça divina, portanto, para Hesíodo, é inerente ao curso dos acontecimentos, e necessariamente se manifesta em conexão com as ações coletivas e individuais dos homens.

Em Os Trabalhos e os Dias, a noção de justiça se descreve mediante as imagens da cidade justa e da cidade injusta (225-48):

Quem dá sentenças a forasteiros e a nativos 225 retas e não transgride nunca o que é justo, tem cidade viçosa, e o povo nela floresce; Paz na terra é nutriz de jovens, nem jamais Zeus previdente lhe suscita dolorosa guerra. Nunca Fome segue homens de retas sentenças, nem Erronia; nas festas têm dos campos cultos. Terra lhes dá muitos víveres: nos montes, roble na alta copa dá bolotas, e no meio, abelhas; lanosos carneiros arcam pesados de tosões; mulheres dão à luz filhos símeis aos pais; vicejam com bens sempre; nem em navios querem ir, e a dadivosa lavoura dá frutos. Aos afins a transgressão vil e feitos cruéis, o Cronida previdente Zeus lhes suscita Justiça. Muitas vezes ainda a cidade toda sofre por mau homem que delinqüe e maquina estultícias. 
O Cronida lhes envia do céu uma grande dor, fome junto a peste, e vai perecendo o povo: as mulheres não procriam, minguam as casas por conselhos de Zeus Olímpio, e ainda aliás ou destrói-lhes vasto exército ou a muralha, ou navios no mar o Cronida lhes faz pagar.

Nesses versos, contrapõem-se dois comportamentos, caracterizados como a prática de dar "sentenças retas" (dikas... itheías, Op. 225-6) e a prática da "transgressão vil" (hýbris... kaké, Op. 238), mostrando-se que as conseqüências de um comportamento se contrapõe às do outro como a participação no ser se contrapõe à privação de ser.

As "retas sentenças" dão condições a que a cidade viceje e o seu povo floresça, a Deusa Paz proteja os jovens, Zeus previdente não suscite guerra, as Deusas Fome e Erronia não se manifestem, a Deusa Terra produza muitos víveres, roble dê bolotas, abelhas dêem mel, carneiros sejam lanosos, mulheres dêem à luz filhos semelhantes aos pais, e com lavoura tão farta, não haja desejo de navegar. Nessa feliz solidariedade entre fenômenos tão diversos é que se manifesta o favor de Zeus à cidade e ao povo: a participação no ser, cheia de vida e de víveres, em paz.

A "transgressão vil e feitos cruéis" dão condições a que a cólera de Zeus se manifeste como justiça punitiva, a suscitar fome, peste, infertilidade humana, escassez de população, a destruição de exército, de muralha e de navios no mar. A solidariedade entre fenômenos díspares, então, mostra a sua face sombria de execução penal: a privação de ser, por escassez, morte e destruição.

No segundo estásimo de As Suplicantes de Ésquilo, as preces das Danaides pelos argivos assim se descrevem: "preces benéficas, prêmios de benfeitores" (eukhàs agathàs agathôn poinás, Supp. 626).

Nessa descrição de "preces" como "prêmios", a ironia divina se manifesta na ambigüidade da palavra poinás, aqui traduzida por "prêmios". Neste verso Supp. 626, o sentido laudatório de "prêmios" é claramente determinado pela enfática reiteração do adjetivo agathàs ("benéficas") como qualificação das preces e dos prêmios, ditos "dos benfeitores" (agathôn). No entanto, em outros versos de Ésquilo, poiné significa "pena", "punição" (cf. barýdikos Poiná, Ch. 936; e ainda Eu. 203, 464, 543, 981; Pr. 112, 176, 223, 268, 620, 564; Ag. 1223, 1340), enquanto em outros versos, nomeia a Deusa “astuciosa Punição” (dolióphron Poiná,Ch. 947) e sua forma de ação, punitiva de mortos e de vivos (alaoîsin kaì dedorkósin poinán, Eu. 323). Estas preces, por serem benéficas, são a recompensa, não a punição, dos benfeitores. 
Além da ambigüidade entre o bem - entendido como participação no ser - e o mal - entendido como privação de ser, - há outra ambigüidade, não tão claramente discernível e muito mais complicada, a saber, entre o que é comportamento de mortais e o que é manifestação divina. Entretanto, nesta palavra Poiné importa ainda outra ambigüidade: a Deusa assim nomeada, por um lado, identifica-se com Justiça (Díke), filha de Zeus, e por outro, com Erínis, filha da Noite.

As preces "prêmios" se descrevem também como "louvor" (timás, Supp. 628), proferido por "hóspede boca" (xeníou stómatos, Supp. 628), tendo-se invocado por testemunha dessas preces Zeus Hóspede (Zeus... xênios, Supp. 627), em cujo âmbito, portanto, se fazem as preces.

Na primeira estrofe do segundo estásimo, invocam-se "Deuses filhos de Zeus" (Theoì Diogenê̂s, Su, 930), suplicando-lhes que Ares não destrua a terra pelásgia. Ares, filho de Zeus e Hera, é o Deus que se manifesta na carnificina, o epíteto miaíphonos ("sujo de sangue"), que o qualifica na poesia de Homero aos trágicos, confirma-se nesta descrição deprecativa: "lúbrico Ares insaciável de gritos, / ceifeiro de mortais nas lavras de sangue (tòn ákoron boân mákhon Áre, / tòn arótois therizonta brotoùs enaímois, Supp. 635-6).

Nesses versos a afinidade de Ares com Afrodite é sugerida pelo adjetivo "lúbrico" (mákhlon), com que, em Os Trabalhos e os Dias, Hesíodo descreve o comportamento que empolga as mulheres no verão (586), e ainda pela imagem de "lavras" (arótois), que significa trabalhos do campo, mas, por metáfora comum na poesia trágica, união sexual e prole. Essa unidade enantiológica, que associa Ares e Afrodite, reponta na designação de Ares como "amante de Afrodite" (Aphrodítas eunátor, Supp. 665). Essa prece a Ares, - associado, ainda que por oposição e contrariedade, a Afrodite, - justifica-se pela atitude temerosa a Zeus Suplicante, revelada no voto do rei e do povo, ao concederem asilo às suplicantes, cujo exílio se dá por fuga a núpcias e assim aos dons de Afrodite (Supp. 637-42).

$\mathrm{Na}$ segunda antístrofe do segundo estásimo, o mesmo voto se explica, tanto como por respeito a "Zeus vingador vigilante" (Dîon... práktor' epískopon, Supp. 656), cuja cólera é incombatível, e cuja presença pesa, grave,- quanto como por respeito às "suplicantes consangüíneas de Zeus Puro” (homaímous Zenòs híktoras hagnoû, Supp. 652). Por esse respeito, também se explica por que o rei e o povo pelásgio têm "altares puros", com que agradarão aos Deuses (katharoîsin bomoîs, Supp. 655). Os adjetivos Hagnós e katharós, um e outro traduzidos por "puros", a meu ver, referem-se à pureza da exclusiva pertinência 
do âmbito próprio do Deus às atribuições próprias do Deus, dito por isso "puro" (Zenòs... hagnô, Supp. 657). Nas associações relativas a Ártemis - mas não nas relativas a Zeus e a Apolo - essa noção de pureza parece implicar castidade e inexperiência sexual. Descrita essa afinidade como a pureza da exclusiva pertinência do âmbito próprio do Deus às atribuições próprias do Deus, por essa afinidade da pureza comum a Zeus, Ártemis e Apolo, os altares se dizem "puros" (katharoîsin, Supp. 655).

Na segunda estrofe do segundo estásimo, a prece - para afastar diversas formas de privação de ser - pede que pestilência não esvazie a cidade, não se manifeste rixa na região, e Ares não colha a flor da juventude, nem devaste o velo, ou seja, a juventude da cidade. Na segunda antístrofe, a prece - para atrair maior participação no ser - pede por altares, freqüentados por anciãos, estejam plenos de oferendas em ação de graças, a cidade bem governada principalmente pelos cultores do grande Zeus e de Zeus Hóspede, a terra seja sempre frutífera, e Ártemis Hécate proteja as mulheres em trabalho de parto (Supp. 656-77).

$\mathrm{Na}$ terceira estrofe, a prece reitera o pedido de que sejam excluídas diversas formas de privação de ser, tais quais massacre homicida, manifestações de Ares e de violência, o triste enxame de doenças, e assim seja o Deus Lupino (Apolo, irmão de Ártemis) benévolo com a juventude. Na terceira antístrofe, a prece reitera o pedido de participação no ser: Zeus torne a terra frutífera e os rebanhos prolíferos, sejam os Numes generosos, e junto aos altares os cantores pela pureza sejam gratos à Musa (Supp. 679-97).

Na quarta e última estrofe do segundo estásimo, a prece se concentra nas formas felizes de exercício do poder e de desempenho político, capazes por si mesmas de afastar a atuação de Ares, nas relações com os vizinhos, e na política interna, a dolorosa necessidade da Justiça em seus aspectos penais (Supp. 698-703).

Na quinta e última antístrofe do segundo estásimo, a prece pede que se perpetuem as honras ancestrais, coroadas de louros e sacrificadoras de bois, aos Deuses, que habitam a terra, e assim se observe a veneração aos pais como norma concernente a Zeus Salvador. A meu ver, o fato de que a veneração aos pais "inscreva-se aqui como terceira entre as leis de Justiça honradíssima" (tríton tód' en thesmiois Díkas gégraptai megistotímou, Supp. 708-9) não implica uma seqüência de primeira, segunda e terceira leis, mas sim uma vinculação entre a veneração aos pais e a justiça distribuída por Zeus Salvador, a quem nas festas se liba em terceiro lugar (Supp. 704-9). 


\section{Anunciam-se os inimigos}

No terceiro episódio, Dânao anuncia a chegada dos Egipcíades, tal como a pode ver de um mirante: primeiro o navio, bem visível, bem se distinguindo as velas, as amuradas e a proa do navio, e a seguir, a tripulação, negros vestidos de alvas túnicas, e ainda mais navios, cuja nau capitânia, com olhos no caminho adiante e com ouvidos no comando do leme, já recolheu vela e remava para a terra. Como fez ao anunciar a chegada da comitiva real (Supp. 176-203), começa e termina o anúncio com uma parênese, que encarece e louva a prudência como a única atitude que pode garantir a Dânao e a suas filhas a possibilidade de saírem-se bem nessa situação (Supp. 710-733).

Em ambos os anúncios, de ambas as chegadas, a atitude prudente, encarecida e louvada pela parênese, encontra respaldo e abrigo no apelo à Justiça divina (Supp. 228-31, 732-3).

Nas quatro estâncias do amoiboion (Supp. 734-63), em que Dânao e o coro alternam o canto, mostra-se o sereno poder persuasivo da palavra de Dânao sobre suas filhas. Na primeira estrofe (Supp. 734-42), quando o pavor as domina e elas se perguntam se houve algum ganho na fuga, o pai responde reafirmando a validade e eficácia do decreto argivo que lhes concede asilo; mas elas contrapõem à segurança desse asilo o caráter sórdido e insaciável de batalha dos inimigos. No segunda antístrofe (Supp. 743-9), quando ao poder beligerante dos inimigos, descrito pelas filhas, Dânao contrapõe a força defensiva dos argivos, elas explicam seu apelo e apego ao pai com a declaração de que mulher a sós não tem valia, porque não participa de Ares, como se o ancião participasse (cf. $A g$. 78). Na segunda estrofe (Supp. 750-6), quando elas descrevem os inimigos funestos, dolosos, ímpios e rapineiros como corvos que espoliam altares, Dânao argumenta que essa transgressão, configurada na atitude e ação dos inimigos, por si mesma atrai a cólera e ódio dos Deuses, mas elas insistem que temor e reverência no trato com o divino não os detêm. $\mathrm{Na}$ segunda antístrofe (Supp. 757-63), quando elas os representam arrogantes, sacrílegos e audazes como cães, Dânao rebate que os lobos - entendamse: homens de Argos, onde se cultua Apolo Lykeîos, "Lupino" - vencem os cães, e o papiro - entendam-se: ribeirinhos do Nilo, nutridos de papiro - não supera a espiga - entendam-se: argivos, nutridos de trigo; e elas concluem que se deve evitar o poder dos que têm sentimentos de feras sanguinárias e ímpias.

Para que suas filhas permanecessem tranqüilas, durante sua ausência enquanto fosse ao encontro do rei Pelasgo, Dânao encoraja-as, alegando 
que o desembarque das tropas inimigas não poderia ser imediato nem iminente, dadas as dificuldades da ancoragem à noite em terra desconhecida. Aconselha-as que por temor não descuidassem dos Deuses, e por fim reafirma sua confiança no compromisso da cidade com o decreto que lhes concedeu asilo (Supp. 764-75).

\section{A morte livre de lúgubres males}

No terceiro estásimo (Supp. 776-824), a primeira estrofe reitera a interpelação à "terra alterosa" ( $g a ̂$ boûni, Supp. 776), cujas colinas invocam a novilha ancestral, a quem se pergunta o que se há de sofrer, e se há - onde há - em Ápia terra "algum negro esconderijo algures", para fugir. "Algum negro esconderijo algures" (kelainòn... ti keûthos... poû, Supp. 778) é uma imagem da invisibilidade de não ser, comparável a "negrifundo esconderijo" (melambathès / keutmón, Pr. 219-20), que, na tragédia de Ésquilo Prometeu Cadeeiro, descreve onde se oculta o antigo Crono, a saber, no Tártaro. Esse sentido de não ser claramente se reitera e assim se explicita como desejo de não ser, por ter-se abolido, expressa na forma verbal oloiman, (Supp. 782, "eu sumisse") e nas imagens "negro fumo" (melas... kapnós, Supp. 779) e "poeira sem asas" (kónis áterthe pterýgon, Supp. 782).

Na primeira antístrofe, esse desejo - de não ser - se renova, com a imagem de laços e enforcamento, "antes que varão deprecado roce esta pele" (Supp. 790), e se reforça com imagem de morte e reino de Hades (Supp. 791).

Na segunda estrofe, as imagens - de não ser, por ter-se abolido, - se diversificam, como "trono no céu" (aithéros thrónos, Supp. 792), "profunda queda", assim descrita (Supp.794-9):
(...) lisa, íngreme, indistinta, solitária, precipitosa pedra de abutres, a testemunhar-me a profunda queda, antes de ter acerbas núpcias violentas ao coração

Na segunda antístrofe, o desejo - de não ser, por ter-se abolido - se reitera e se reforça, com a imagem de ser "presa de cães e pasto de pássaros" (Supp. 800), respaldando esse voto com a expectativa de que “ (...) a morte libertará / de lúgubres males" (Supp. 802). Aceita-se que a via de fuga das núpcias possa ser a morte, conquanto seja "livre de núpcias" (gamô̂ lytêra, Su 807), pois essas núpcias equivalem a lúgubres males. 
Na terceira estrofe, exorta-se a estridular ao céu cantos precatórios aos Deuses, que se cumpram com a libertação das núpcias e dos males, sob o olhar justo de Zeus. Fundamento da justiça, Zeus onipotente sustenta também a terra (gaiáokhe pagkratès Zeû, Supp. 816).

A terceira antístrofe define o crime e acusa o seu autor, perante a justiça de Zeus - a insuportável transgressão, própria de varões, perpetrada pelos Egipcíades, ao perseguirem e forçarem núpcias (817-24).

\section{A imagem vã e o sonho negro}

Com hipótese fundada em parte nos poderes divinatórios de sua ciência ecdótica e em parte nos poderes encantatórios da Deusa Persuasão (cf. thélktori Peithô̂, Supp. 1040), M.L. West restaura os severamente fragmentários versos Supp. 825-6c e, seguindo uma proposta de Wilamowitz, retomada por Murray e por Johansen-Whittle ${ }^{6}$, atribui-os ao coro dos Egipcíades, que se acrescenta ao das Danaides, compondo-se assim a primeira cena (Supp. 825-910) do quarto episódio (Supp. 825-1017) com dois coros, o de Egipcíades contraposto ao de Danaides, e o ator, que representa o arauto dos Egipcíades e que responde - como convém a um arauto - com um discurso, e não com canto, ao canto das Danaides.

Aceites a restauração e atribuição feitas por M. L. West dos versos Supp. 825-6c, o coro dos Egipcíades se identifica tal como as Danaides os caracterizaram: como o raptor que transpôs o mar e prossegue por terra o seu funesto intento de perpetrar a transgressão configurada nesse rapto.

A fala do raptor (Supp. 825-6c), por sua violência transgressora, suscita primeiro a deprecação, proferida pelo corifeu do coro das Danaides, de que o raptor pereça - invisível, destruído, ao voltar ao mar (Supp. 827-8). A seguir, o lamento pela própria sorte e a previsão de duros males a quem concede asilo às Danaides (Supp. 829-30). Nessas circunstâncias, resta ainda fugir para o abrigo (alkán, Supp. 833) - dado pelo altar e pelas imagens dos Deuses agónioi (“juntos”, cf. Supp. 189, 242 329, 355). Nessas circunstâncias, como se mostram os inimigos? Marcados pelo orgulho da violência, assinalados para dificuldades, tanto em navio, quanto na terra. Ante tais inimigos, além do abrigo das imagens divinas, pede-se a proteção do rei da terra (Supp. 833-5).

A fala do inimigo anuncia violência e rapto (Supp. 836-40). Assim o inimigo se mostra - aos olhos das Danaides - a eloqüente imagem da

${ }^{6}$ Ver West ad loc. e Johansen-Whittle, v. 3, p. 172 e seg. 
“despótica transgressão" (desposíoi xyn hýbris, Supp. 845), cuja eloqüência anuncia a sina de perecer - punido pelos Deuses.

No primeiro par de estrofe e antístrofe, o coro de Egipcíades contrapõe ordens urgentes, violência verbal e intimidação - ao canto deprecatório do coro das Danaides; a seguir, em mais dois pares de estrofe e antístrofe, o arauto contrapõe ordens intimidativas e declarada ignorância dos Deuses locais - ao continuado canto deprecatório do coro de Danaides (Supp. 842-910).

A violência contra suplicantes, perante os altares e as imagens dos Deuses, leva o coro de Danaides a declarar vão o "auxílio da imagem" (bréteos aros, Supp. 885, segundo M.L. West ${ }^{7}$ ) a declarar-se conduzidas ao navio - como aranha passo a passo - por um sonho negro (ónar ónar mélan, Supp. 886-8) e - no estribilho - invocar mãe Terra, o rei filho da Terra e Zeus (Supp. 889-92). A meu ver, neste contexto, "negro" (mélan, Supp. 888) significa "meôntico", i.e. uma forma de privação de ser: esse "sonho negro" conduz quem o vê à destruição e à morte.

Quando o arauto declara não temer os Numes locais, por não lhes dever nem a educação na infância nem o sustento na velhice, o coro das Danaides o descreve como "bípede serpente" (bipous óphis, Supp. 895), "víbora" (ékhidna, Supp. 896) e "monstro" (dákos, Supp. 898), e - no estribilho - invoca mãe Terra, o rei filho da Terra e Zeus (Supp. 901-3).

Ante a iminência da violência anunciada, o coro das Danaides invoca os "chefes guias da cidade" (póleos agoì prómoi, Supp.905) e o "rei" (ánax, Supp. 908); o arauto replica que elas terão muitos reis, filhos de Egito (Supp. 906-7) e que elas serão puxadas pelos cabelos, por não ouvirem bem as ordens do arauto (Supp. 909-10).

\section{$\mathrm{O}$ rei e o arauto}

O diálogo do rei e do arauto se enviesa, de modo que o rei não se dirige ao arauto como a um arauto, mas a cobrar do arauto explicação do que o vê fazer e respeito pela terra dos varões pelasgos, nem o arauto em sua função de arauto se dirige diretamente ao rei como a um rei. Esse enviesamento se prolonga num reconhecimento de iminente estado de guerra.

O viés primeiro se manifesta na interpelação e reprovação do rei ao arauto (Supp. 911-5):

\section{${ }^{7}$ Nota 3.}


Ó tu, que fazes? Com que intenção desonras esta terra de varões pelasgos?

Ou pensas vir a uma cidade de mulheres?

Se és peregrino, vituperas demais os gregos

e em grande erro não corrigiste o espírito.

O viés, pois, consiste nesse "grande erro" (poll’hamartón, Supp. 915) que o rei vê no arauto. $\mathrm{O}$ arauto replica com a questão da justiça: que há de injusto em seus erros, suposto que sejam erros. O erro - e implícito o que há de injusto - consiste primeiro em não saber ser hóspede (xénos, Supp. 917). Ao apontar para a condição de hóspede, assim o rei esclarece que a injustiça diz respeito a Zeus Hóspede (Xénios, Supp. 627,672). O arauto, ao replicar que achou o que perdera e assim o leva consigo, assinala que serve a "Hermes, patrono máximo, buscador" (Hermêi, megístoi proxénoi, masteríoi, Supp. 920).

O rei redefine o erro, de que acusa o arauto, reformulando-o como uma falha na veneração devida aos Deuses (Supp.921). O arauto se defende alegando que venera os Numes que protegem o Nilo, o que permite ao rei dar mais exatidão à acusação que faz, ao esclarecer que o arauto não mostra veneração aos Numes “daqui” (hoi d'enthád', Supp. 923), negando-se a conceder hospitalidade ao arauto, a quem acusa de saquear os Deuses (Supp. 927).

Diante dessa acusação, o arauto recobra o sentido de sua função, ao considerar a possibilidade de apresentar aos filhos de Egito esse viés hermenêutico com que se propõe à compreensão de como age o arauto. Assim o arauto finalmente se apresenta como arauto, ao perguntar a quem deve anunciar como seqüestrador do "consobrinho bando de mulheres" (Supp. 933), que será reclamado por Ares, com perda de varões e extermínio de vidas (Supp. 934-7).

Quando o arauto assim se apresenta como arauto, o rei não por isso se apresenta como rei, mas esclarece de que se trata: não se admite violência a esse bando de mulheres, por decreto público da cidade; portanto, resta a quem contrarie o decreto, tornar-se invisível o mais rápido possível (Supp. 938-49). O arauto, então, se permite declarar como vê a situação configurada pela fala do rei, a saber, - já o início de nova guerra. Além disso, o arauto se permite formular os seus votos, não sem ironia: "sejam dos varões a vitória e o poder" (Supp. 951).

O rei se limita a responder à ironia, esclarecendo que os varões, moradores desta terra, não bebem cerveja de cevada (Supp.952-3). Em seguida, dirigindo-se ao coro das Danaides, descreve as possibilidades de domicílio à disposição dos hóspedes da cidade, exortando-as a escolher e servir-se. 
O coro de Danaides em retribuição faz votos de prosperidade ao povo pelasgo e pede a presença de seu pai Dânao, para que possam decidir onde terão domicílio nesse país estrangeiro. Preparando-se para o êxodo, o coro pede às suas servas (?!) que, confiantes na palavra dos argivos, disponham-se como Dânao as distribuiu por dote a cada uma das Danaides (Supp. 975-9).

\section{O pai e as filhas}

Nessas circunstâncias de escolherem como residir em país estrangeiro, Dânao - pai guia do conselho e guia do dissídio (Danaòs dé, patér kaì boúlarkhos kaì stasíarkhos, Supp. 11) - como ao preparar suas filhas para a iminente interpelação do rei (Supp. 176-203) - primeiro mostra quanto já lhes valeram seus conselhos em situação de extremo perigo (Supp. 176-9, 980-90) e em seguida dá seus conselhos (Supp. 180-203, 991-1013). Em ambas as ocasiões, a parênese da prudência se faz no início e no fim da fala, mas o que diz "prudência" ("prudente", phroneîn... phronoûnti, Supp. 176; sophronôn, Supp. 198, "prudência", tò sophreîn, Supp. 1013) na nova situação assume nova nuance de sentido: antes era a condição da sobrevivência, depois se mostra o dever de honra mais estimável que a vida (Supp. 1013).

Antes, se os prudentes conselhos do pai trouxeram sãs e salvas as filhas de navio, prudência igual à do pai a elas se pedia como a condição da sobrevivência delas. Agora, o pai se apresenta com a segurança da companhia de lanceiros que lhe fora concedida pelos argivos. Que significa dispor de uma companhia de lanceiros para a sua segurança pessoal? Para os atenienses contemporâneos de Ésquilo e de Heródoto, um passo bem dado na direção de se apossar do poder por instalação de um governo tirânico, como lhes mostrou a tomada do poder em Atenas por Pisístrato (Heródoto, 1.59.4-5).

Essa "honrosa prerrogativa" (tímion géras, Supp. 896), concedida a Dânao pelos argivos, justifica-se porque, dada a sua dupla condição de asilado em Argos e de suplicante dos Deuses dessa terra, sua morte sob a sanha dos inimigos seria então uma poluência insuportável para a terra argiva (Supp. 987-8).

Por essa "honrosa graça" (khárin... timiotéran, Supp. 990), Dânao não só se propõe agradecer aos argivos, como a Deuses Olímpios, fazendo-lhes sacrifícios, vertendo-lhes libações (Supp. 980-2) e venerandoos (Supp. 990), mas também exorta às filhas "não o envergonharem" (mè kataiskhýnein emé, Supp. 996). 
O pai compara “este viço notável aos mortais” (hóran... ténd' epistrephon brotoîs, Supp. 997), que distingue suas filhas, a "frutos gotejantes” (karpómata stázonta, Supp. 1002 West), de que Afrodite é arauto, ao mesmo tempo que os amadurece antes da hora, de modo a provocarem as loucuras por amor (Supp. 1002-3 West). É no âmbito de Afrodite, pois, que pede "prudência" às filhas, doravante no trato com os amigos argivos $\mathrm{e}$ - eventualmente - inimigos.

No entanto, quando Dânao adverte as filhas de que não dêem "vergonha a nós e prazer aos inimigos" (med' aîskhos hemîn, hedonèn d' ekhthroîs emoîs, Supp. 1008), com a palavra "inimigos" (ekhthroîs), não se refere somente aos antigos inimigos Egipcíades, e com a palavra "prazer" (hedonèn), não se refere tanto aos dons de Afrodite, quanto ao prazer fortuito do inimigo que vê o inimigo arruinar-se.

O coro de Danaides reconforta Dânao com votos de que Deuses Olímpios lhes dêem boa sorte e com a promessa de conservarem o antigo traço do espírito - vestígio que remota à avoenga Io - na vigilância e guarda do fruto maduro de Afrodite (Supp. 1014-7).

\section{Ártemis e Citeréia}

No êxodo, os dois primeiros pares de estrofe e antístrofe configuram uma antilogia, em que se contrapõem dois diversos discursos e duas diversas atitudes diante de uma mesma situação, a saber, a situação das Danaides, asiladas e domiciliadas em Argos, diante de seus eventuais raptores, os recém-chegados Egipcíades.

O coro I (Supp. 1018-33) - das Danaides - descreve sua atitude perante os Deuses da terra hospedeira, concluindo com uma prece a Ártemis, dita "pura" (Árthemis hagná, Supp.1030) e com votos reiterativos de seus propósitos quanto a núpcias com Egipcíades ("estígio seja este prêmio", stygeròn péloi tód' áthlon, Supp. 1033).

O coro II (Supp. 1034-51) - cuja identidade não se determina claramente, podendo ser atribuído 1) ao grupo de servas mobilizadas pelas Danaides em Supp. 975-9, ou 2) à companhia de lanceiros a serviço da segurança pessoal de Dânao descrita em Supp. 985 -contém uma prece a Cípris, cujo poder e domínio se descreve (Supp. 1031-42), e uma reflexão sobre a impenetrável opacidade do destino e dos desígnios de Zeus (Supp. 1043-51).

No terceiro par de estrofe e antístrofe (Supp. 1052-61), as duas posições, que se contrapõem nessa antilogia dos coros I e II, buscam um ponto de equilíbrio entre ambas, mediante réplicas e tréplicas, suscitadas 
inicialmente pela reiterada prece a Zeus do coro de Danaides para que afaste as núpcias dos Egipcíades (Supp. 1052-3). Aos votos formulados nessa deprecação das núpcias, o coro II, contrapondo-se, então, considera a hipótese da possibilidade de que essas núpcias dos Egipcíades fossem o melhor (Supp. 1054-5): "isto poderia ser o melhor, / tu encantarias o semencanto", tò mèn àn béltaton eíe, / Sy dè thélgois àn áthelkton.

Quando se descreveu o poder e domínio de Afrodite, entre seus filhos Desejo e Harmonia, Persuasão se definia pela qualidade "a quem nada se nega" e pelo epíteto "encantadora" (thélktori, Supp. 140). Portanto, nessa supracitada réplica do coro II, "encantarias" significa a possibilidade de persuadir o impersuadível, por participação em Afrodite, visto que Persuasão é tão filha de Afrodite quanto Desejo e Harmonia.

O coro de Danaides treplica que quem assim pensa não conhece o porvir (Supp. 1061).

Na terceira antístrofe (Supp. 1057-61), o coro II subsume o desconhecimento do porvir à invisibilidade dos desígnios de Zeus, e faz às Danaides a advertência de que fossem "comedidas", como se as aconselhasse a fazer uma prece comedida (Supp.1061): “com Deuses, sem excessos, tà Theôn medèn agázein.

No quarto e último par de estrofe e antístrofe (Supp. 1062-73), o coro de Danaides reitera a prece a Zeus, para que se frustrem as indesejáveis núpcias dos Egipcíades, fundando suas esperanças no mitologema do resgate de Io pela benevolente violência de Zeus, com o que a vitória poderia ser das mulheres (Supp. 1062-8). O coro II declara sua aprovação à "melhor parte do mal" e assim a "meio quinhão" - podendo-se entender que o mal seja a guerra dos Egipcíades e sua melhor parte seja a vitória dos argivos patronos das Danaides, com o que se perfaz "meio quinhão - e declara também sua aprovação a que as sentenças humanas sigam à Justiça divina, com suas preces pela intervenção divina que os livre do mal.

\section{TitLe. The prayer to Zeus god of suppliants in Aeschylus' Suppliants}

AвSTRACt. In Aeschylus' tragedies, the "tragic dialectics" as well as the notions and images, peculiar to archaic Greek mythical thought, are at work to elaborate the political thought that reflects on the limits of any exercise of power, the relationships of power and the matter of Justice in the pólis. This paper aims at giving evidence of that hypothesis of the "tragic dialectics" by the examination of Aeschylus' tragedy Suppliants.

Keywords. Aeschylus; tragedy; The Suppliants; mythical thought; political thought; tragic dialectics. 